\title{
Combined effects of cadmium and salinity on development and survival of herring eggs*
}

\author{
H. von Westernhagen, H. Rosenthal \& K.-R. Sperling \\ Biologische Anstalt Helgoland (Zentrale); \\ Hamburg 50, Federal Republic of Germany
}

\begin{abstract}
KURZFASSUNG: Kombinierte Wirkungen von Cadmium und Salzgehalt auf Entwicklung und Überleben von Heringseiern. Eier des herbstlaichenden Ostseeherings (Clupea barengus L.) wurden in natürlichem und in Cadmium kontaminiertem Seewasser (Konzentrationen: 0,1; $0,5 ; 1,0 ; 5,0 \mathrm{ppm} \mathrm{Cd})$ bei verschiedenen Salzgehalten $(5 \%, 16 \%, 25 \%, 32 \% 0)$ erbrütet. Die Toxizität von $\mathrm{Cd}$ wurde im Hinblick auf folgende Kriterien bewertet: Embryoaktivität und Oberlebensraten bis zum Schlupf, Veränderungen der Eimembran, Verschiebung des Schlupfzeitpunktes, Unterschiede in den Schlupfraten, Anteil der lebensfähigen Larven und deren mittlere Totallänge sowie Durchmesser der Augen und Gehörkapseln frischgeschlüpfter Larven. Darüber hinaus wurde die Aufnahme von $\mathrm{Cd}$ in Abhängigkeit von Konzentration und Salzgehalt im Verlauf der Embryonalentwicklung bestimmt. Die Beeinträchtigung der Heringsembryonen durch $\mathrm{Cd}$ war in brackigem Wasser stärker als in unverdünntem Meerwasser. Auch die konzentrationsabhängige Aufnahme von Cd nahm mit sinkendem Salzgehalt des Erbrütungsmediums zu.
\end{abstract}

\section{INTRODUCTION}

Cadmium, a biologically non-essential heavy metal, is normally found in minute amounts in sea water (GolDBerg 1965). In Atlantic offshore waters concentrations are usually not higher than $0.4 \mathrm{ppb}$ with a geometric mean at $0.04 \mathrm{ppb}$ (PRESTON 1973). Chester \& STONer (1974) found even lower values ranging between 0.02 and $0.18 \mathrm{ppb}$. In United States continental shelf waters, concentrations range between 0.06 and $0.11 \mathrm{ppb}$ (WINDOM \& SMITH 1972). In North Sea waters, concentrations of 0.01 to $0.62 \mathrm{ppb}$ (Preston 1973) and 0.024 to $0.25 \mathrm{ppb}$ (Mullin \& Rilex 1956) are considered normal. In the Baltic Sea, equally low mean concentrations of 0.17 to $0.22 \mathrm{ppb}$ have been recorded in open waters (KREMLING 1973). Apart from geological sources, additional cadmium enters coastal areas as a result of industrial activities such as zinc refining and mining, cadmium plating and alloy manufacture, pesticides and fertilizer sources (especially phosphate fertilizers) and paint and pigment manufacture. An increasing number of recent reports indicate that in river estuaries (BUTTERWORTH et al. 1972) and near shore waters of heavily industrialized areas

* This study has been financially supported by the Deutsche Forschungsgemeinschaft (Grant No. Ro 380/2). 
(Preston et al. 1972, Jones et al. 1973), cadmium content of sea water has risen appreciably (AbDullat et al. 1972). In the inner part of the Oslofjord, ANDERSEN et al. (1973) found cadmium concentration to be between 0.67 and $0.92 \mathrm{ppb}$ and cadmium levels in decapitated and eviscerated herring and sprat to vary from 0.2 to $0.7 \mathrm{ppm}$ (dry weight basis). The high cadmium levels in parts of the Severn estuary are also reflected in high accumulation levels in Littorina (178 ppm) and Fucus (53 ppm) (LeATHERLANd \& BURTON 1974).

Of many aquatic poikilothermic organisms, fishes appear to be most resistant to the effects of heavy metals (SCHWEIGER 1957, ExSLER 1971). Invertebrates such as molluscs and crustaceans have been shown to be more sensitive to the toxic action of these pollutants (Schweiger 1957, Brown \& Ahsanullah 1971, Eisler 1971, Biesinger \& Christensen 1972, O'Hara 1973b, Thurberg et al. 1973).

Although it is known that larvae of oysters and crustaceans are up to a thousand times more susceptible to heavy metals than adults of the same species (ConNor 1972), little work has been done on the influence of metals on the early stages of fishes. Pickering \& GAST (1972) found reduced survival in embryos of the fathead minnow Pimephales promelas reared in water containing more than $57 \mu \mathrm{g} \mathrm{Cd} / 1$. RosentHal \& SPERLING (1974) showed that herring eggs, incubated in sea water of about $16 \%$ salinity and a cadmium concentration of $1.0 \mathrm{ppm}$, yielded a very low percentage of viable larvae $(16.3 \%$ ) compared to $93 \%$ in the controls. At $5.0 \mathrm{ppm}$ no viable hatch occurred.

The tolerance of aquatic organisms to cadmium varies considerably. In fresh water, tolerance limits for cadmium are to a great extent dependent on the hardness of the water (PICKering \& Henderson 1966). In sea water, salinity seems to have a comparable influence on the toxicity of this metal. Olson \& Harrel (1973), using the bivalve Rangia cuneata, proved that the toxic action of copper, mercury and chromium was mitigated in water of high salinities.

The present study was established to examine the influence of cadmium on embryonic development of the herring Clupea harengus L. from the Baltic Sea under different salinities. The cadmium concentrations employed in this series of experiments were selected in order to obtain visible deviations from normal embryonic development resulting from short time exposure.

\section{MATERIAL AND METHODS}

Eggs of Baltic autumn spawning herring were artificially fertilized in sea water of $5,16,25$, and $32 \% \mathrm{~S}$ at a temperature of $10^{\circ} \mathrm{C}$. Immediately after fertilization the eggs were transferred into aerated $2 \mathrm{I}$ incubation jars containing natural sea water (controls) and test solutions of $0.1,0.5,1.0$ and $5.0 \mathrm{ppm} \mathrm{Cd}^{++}$. The test media were renewed every other day, while salinity and $\mathrm{pH}$ values $(7.53-8.10)$ were determined immediately before and after each renewal. The test solutions were prepared by adding $\mathrm{CdCl}_{2}$ from a stock solution immediately before each renewal. Temperature readings and water samples for cadmium determination were taken daily. Cadmium working levels maintained in test solutions throughout the experiments were at about $80 \%$ 
of the initial concentration. Egg samples (5 each) were preserved at different ontogenetic stages. Determination of cadmium uptake in herring embryos was accomplished by means of AAS (Perkin Elmer 'Type 300) as described by Rosenthal \& SPERLING (1974).

In order to assess possible changes in the toxic effects of cadmium at different salinities, the following criteria were used: rate of embryonic survival (daily counts); embryonic activity (number of embryo movements per $3 \mathrm{~min}$ ); effects on egg membrane; incubation time (time from fertilization to $50 \%$ hatching); hatching rates (observed in $24 \mathrm{~h}$ intervals); percentage of viable hatch; mean total length and yolk sac length of newly hatched larvae, diameter of eyes and otic capsules; cadmium uptake of eggs during the course of embryonic development.

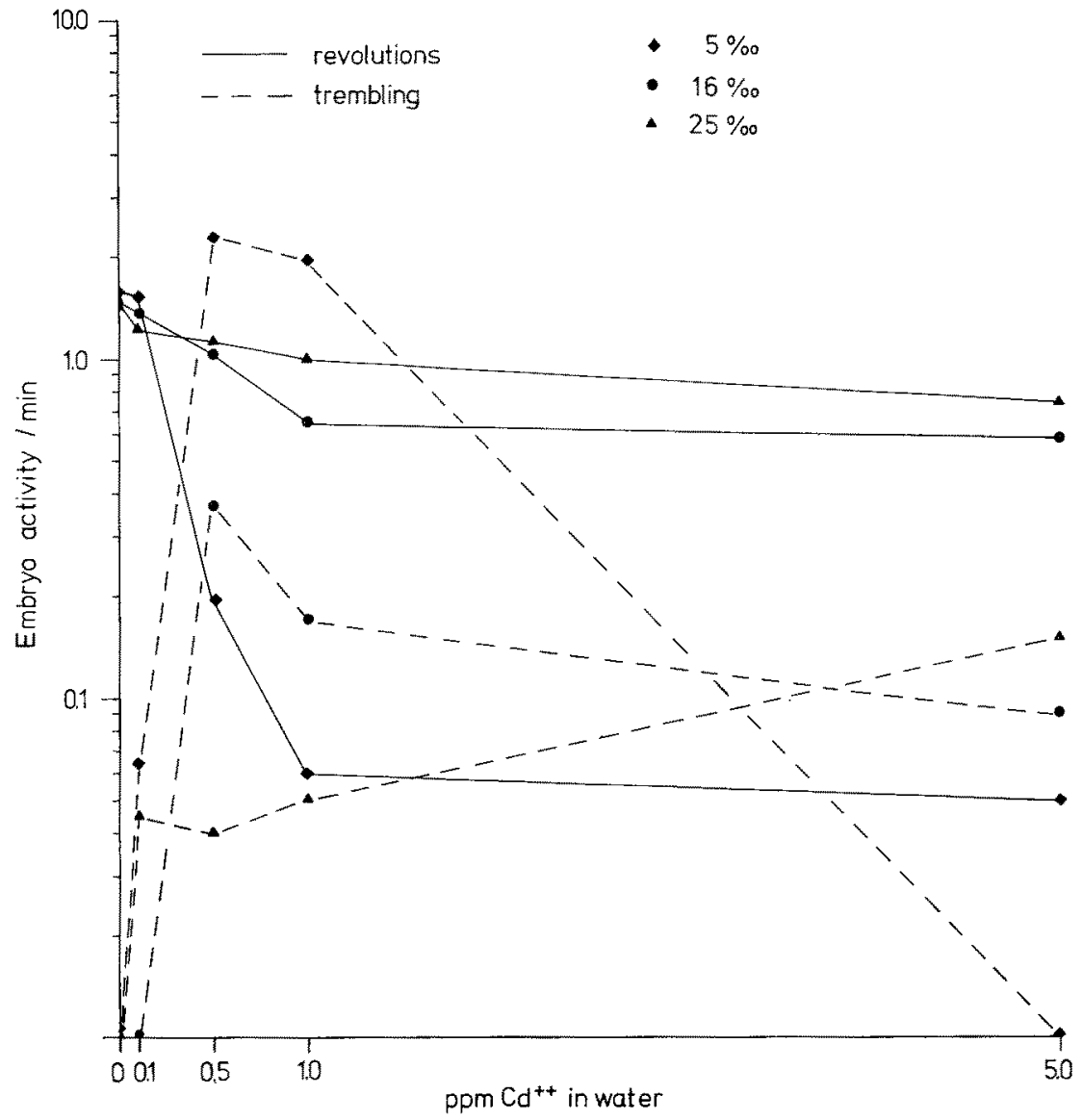

Fig. 1: Clupea barengus embryos incubated at different salinity-cadmium concentrations. Mean number of activities per minute measured $24 \mathrm{~h}$ prior to hatching. Solid line $=$ complete revolution; broken line $=$ slight movements and "trembling". Incubation temperature $10^{\circ} \mathrm{C}$ 


\section{RESULTS}

\section{Embryonic activity}

At a certain developmental stage herring embryos perform rotations within their egg capsule (Holliday et al. 1964, RosentHal 1966). This is presumed to circulate the perivitelline fluid thus improving oxygen provision of the embryo. In herring eggs incubated in cadmium contaminated water, changes in this behaviour became apparent. Depending on cadmium concentration, embryos displayed "trembling"motions of the whole body and fewer rotations occurred. Embryonic activity in contaminated water was also influenced by the salinity of the incubation medium. Figure 1 shows embryonic activity $24 \mathrm{~h}$ before hatching. Effects of cadmium on embryonic activity were most pronounced in highly diluted sea water of $5 \% \mathrm{O}$. There was no trembling behaviour in the controls. A $32 \% \mathrm{~S}$ no activity measurements were conducted.

Thus the detrimental effect of cadmium on the embryonic activity was most apparent in diluted sea water. The action of the metal diminished as salinity of the incubation medium increased.

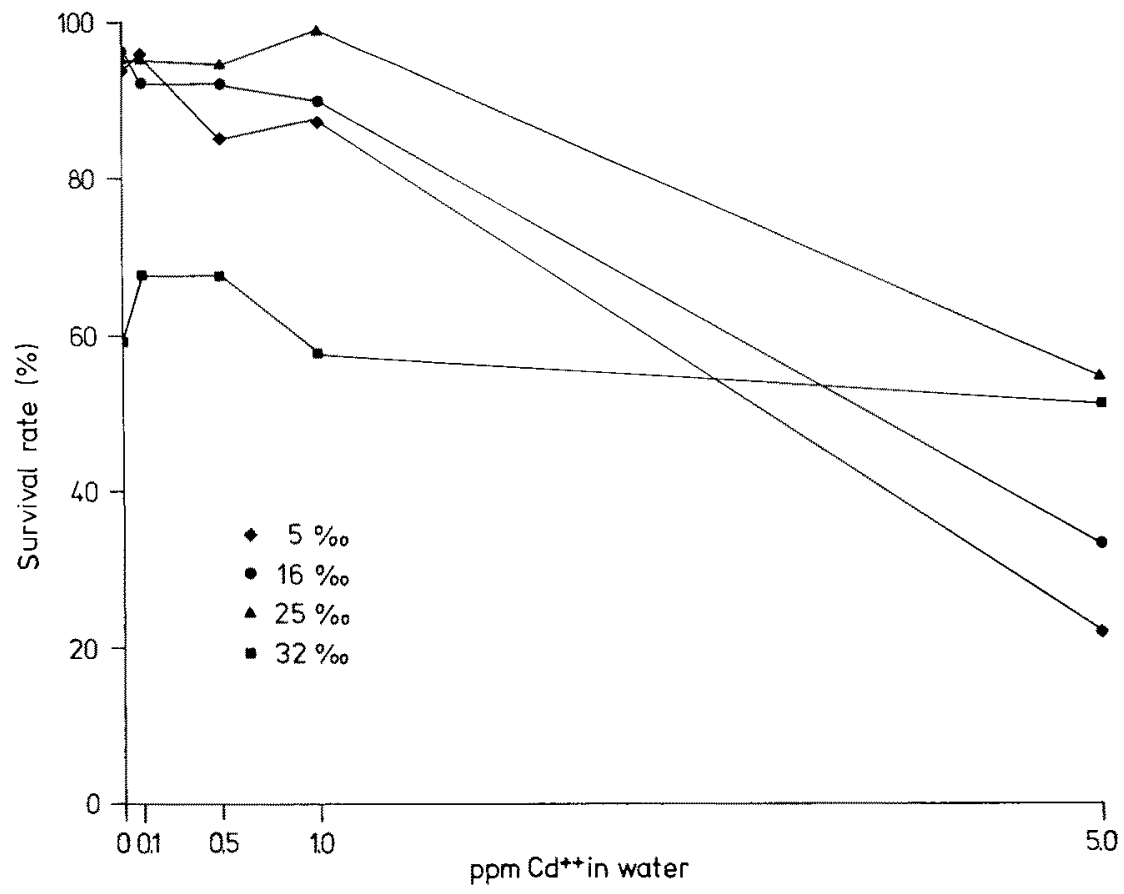

Fig. 2: Clupea harengus eggs incubated at different salinity-cadmium concentrations. Survival rates until hatching in \% of fertilized eggs. Incubation temperature $10^{\circ} \mathrm{C}$ 


\section{Egg membrane}

During the course of development, the chorion of eggs incubated in highly contaminated water became dark and less transparent, suggesting that it was directly affected by the cadmium. Also the softening of the chorion under cadmium influence, described by Rosenthal \& SperLing (1974), was observed in all salinities investigated. Egg diameter was not altered by the Cd content of the incubating medium. As development proceeded, eggs reared in cadmium contaminated water became less tightly attached to the incubating panes and burst easily when removed.

\section{Embryonicsurvivaluntil hatching}

Survival of fertilized eggs in cadmium solutions of up to $1.0 \mathrm{ppm}$ was comparable to that in the controls. Rates of survival decreased considerably in $5.0 \mathrm{ppm} \mathrm{Cd}$, being lowest at 5 and $16 \% \mathrm{~S}(21.7 \%$ and $32.8 \%$, respectively) and highest at 25 and $32 \% \mathrm{~S}(54.9 \%$ and $51.0 \%$, respectively). In 5,16 , and $25 \% \mathrm{~S}$ and in controls, $0.1,0.5$ and $1.0 \mathrm{ppm} \mathrm{Cd}$ hatching rates were high, ranging from $85 \%$ to $99 \%$ of fertilized eggs. Survival rates at $32 \% \mathrm{~S}$, being generally lower than in less saline water and never exceeding $67 \%$, did not show as spectacular a drop for high cadmium concentrations as found in other salinities (Fig. 2).

\section{Incubation period}

Figure 3 shows hatching distribution at $24 \mathrm{~h}$ intervals at different salinities and cadmium concentrations. Cadmium concentrations higher than $0.1 \mathrm{ppm}$ were generally associated with earlier hatch. This was true for all salinities employed, except for the $5 \% \mathrm{~S} / 5.0 \mathrm{ppm} \mathrm{Cd}$ trial, where $50 \%$ hatching occurred much later than in the other experiments. However, the hatching process in this trial was abnormal. The embryos, having died prior to or immediately after hatching, were only liberated after the membranes disintegrated due to continued action of released hatching enzymes.

\section{$\mathrm{Viable} \mathrm{hatch}$}

At $25 \%$ and $32 \% \mathrm{~S}, 94 \%$ to $97.5 \%$ of the total hatch appeared viable in cadmium concentrations of up to $1.0 \mathrm{ppm}$ (Fig. 4). At $16 \% \mathrm{~S}$ and $1.0 \mathrm{ppm} \mathrm{Cd,} 61.5 \%$ of the hatched larvae were considered viable, while at $5 \% \mathrm{~S}$ hatch was already below $90 \%$ in $0.1 \mathrm{ppm} \mathrm{Cd}$ and near zero in $0.5 \mathrm{ppm} \mathrm{Cd}$. No viable larvae were obtained in $5.0 \mathrm{ppm} \mathrm{Cd}$ in any of the salinities tested. Subdividing the non-viable larvae into bent, crippled and dead specimens (Fig. 5) allows further insight into the effect of cadmium on the developing eggs of the herring. At $5 \% \mathrm{~S}$, larvae were most severely damaged $(70 \%$ dead at $5.0 \mathrm{ppm} \mathrm{Cd,} 100 \%$ crippled at $1.00 \mathrm{ppm} \mathrm{Cd})$. At $16 \% 0 \mathrm{~S}$ and $0.5 \mathrm{ppm} \mathrm{Cd}, 2 \%$ of the larvae were dead and $98 \%$ were crippled; at $1.0 \mathrm{ppm} \mathrm{Cd}, 24.5 \%$ were crippled and $14 \%$ displayed a bent longitudinal body axis. 


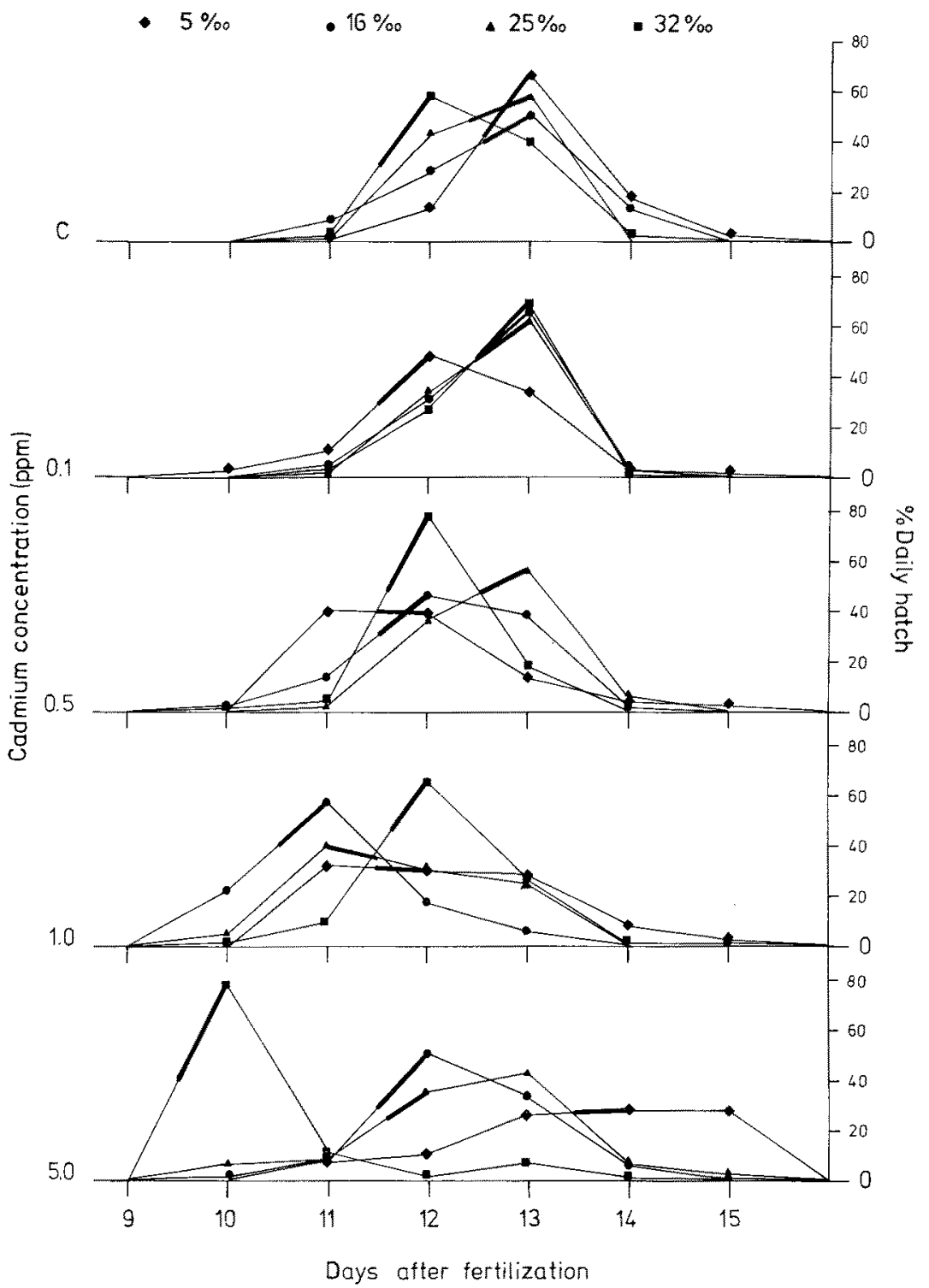

Fig. 3: Clupea harengus larvae incubated at different salinity-cadmium concentrations. Hatching distribution (\% day) and $50 \%$ hatching time (dark bars). Incubation temperature $10^{\circ} \mathrm{C}$

Meantotal length of larvae at hatching

Measurements of mean total length of larvae were only possible for straight specimens. The available data show that in all tested salinities larval size decteased 


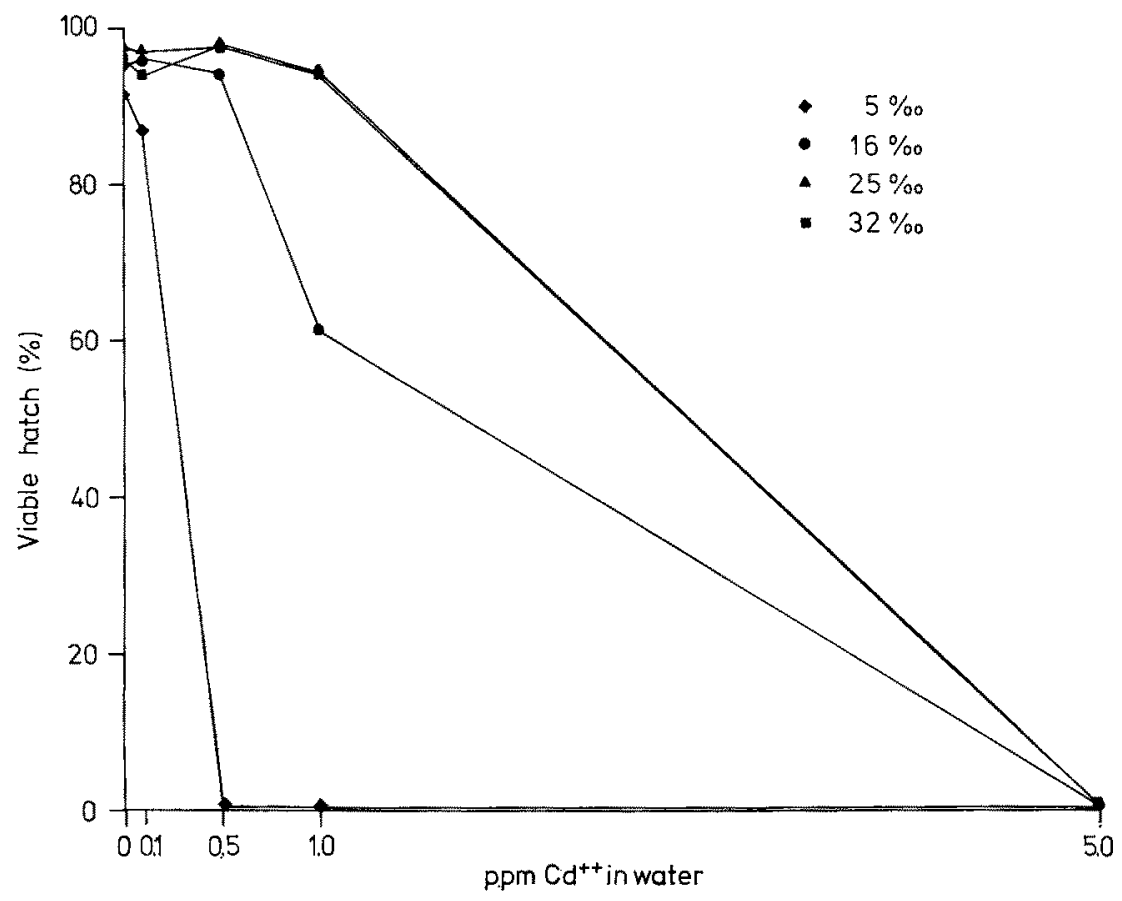

Fig. 4: Percentage viable hatch of herring larvae (Clupea barengus) incubated at different salinity-cadmium concentrations at $10^{\circ} \mathrm{C}$

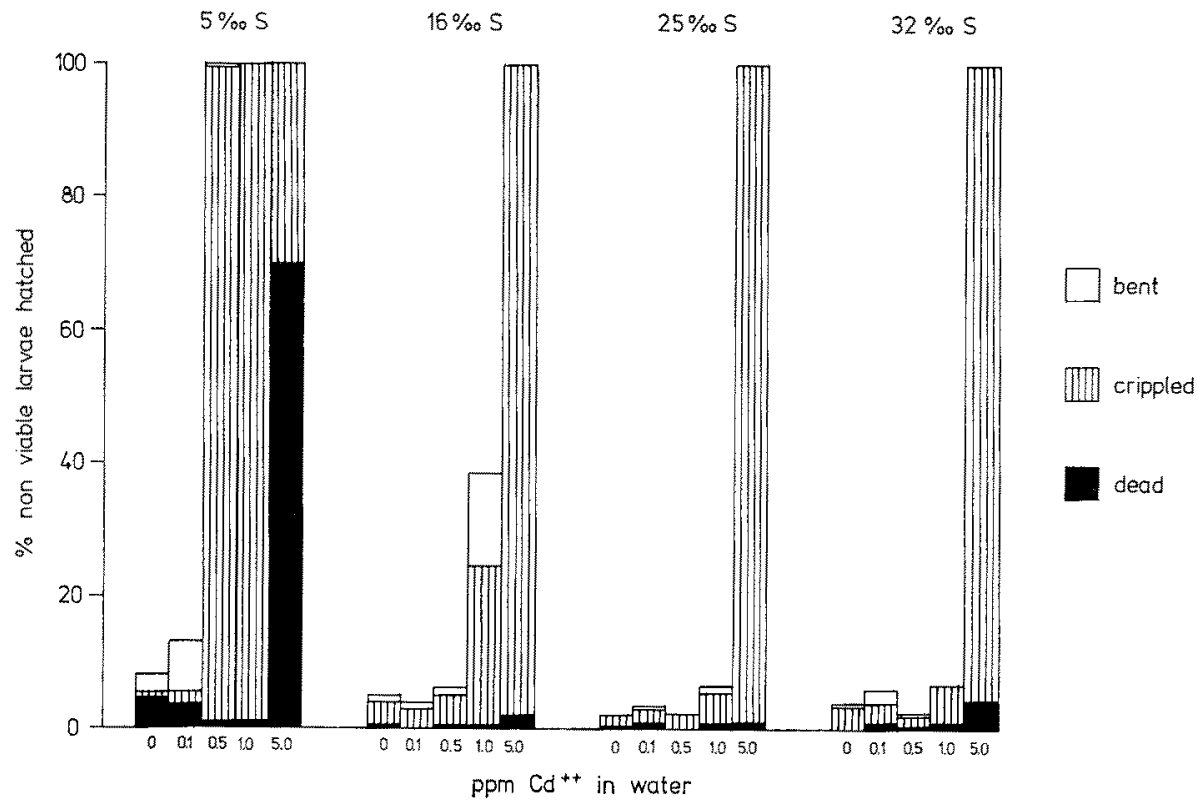

Fig. 5: Clupea harengus. Rates of malformation and lethal hatch $(\%)$ of larvae incubated at different salinity-cadmium concentrations at $10^{\circ} \mathrm{C}$ 


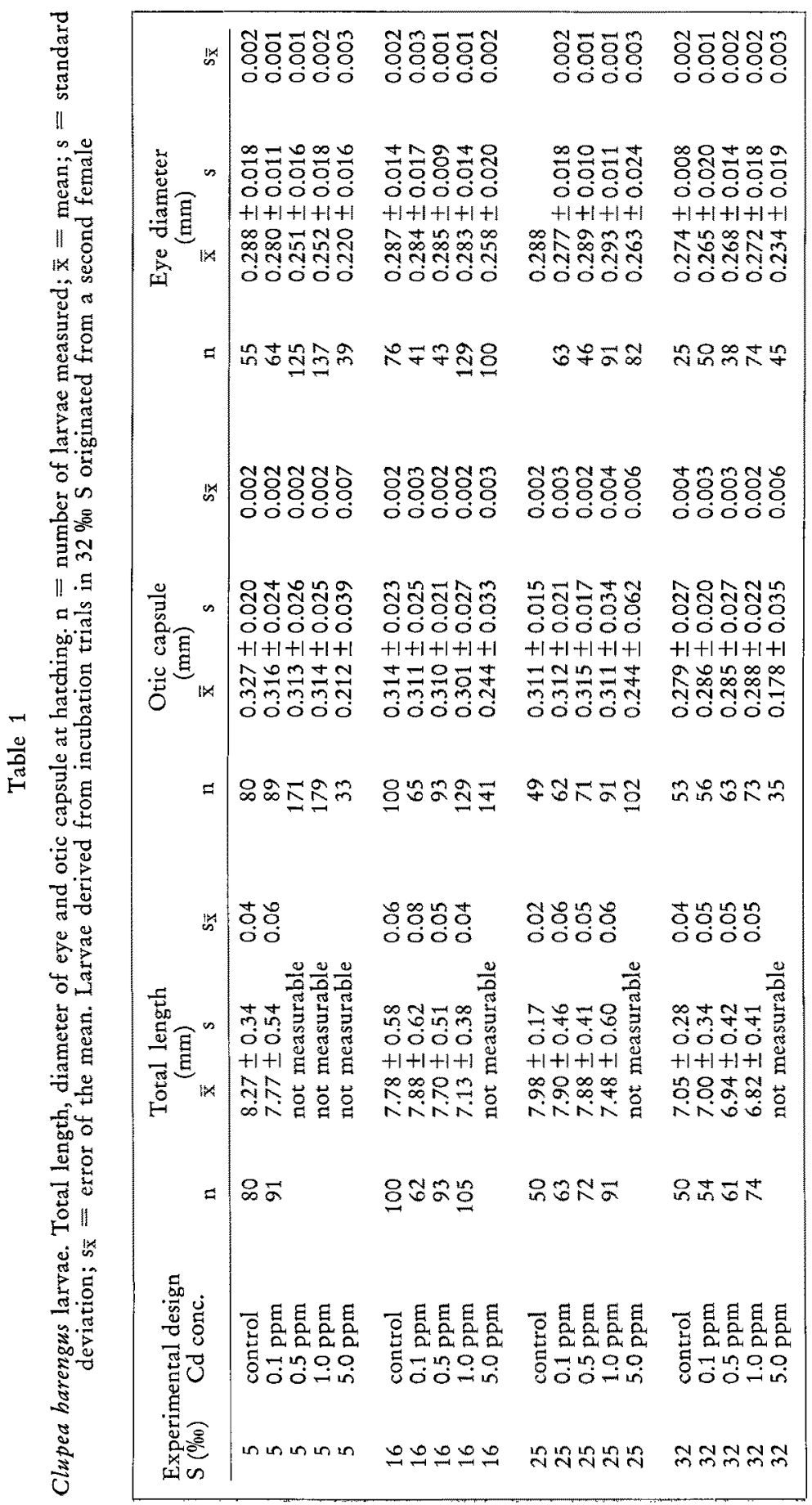


with increasing cadmium concentration. The relative decrease in mean total length was least in $32 \% \mathrm{~S}$, showing only $0.24 \mathrm{~mm}$ difference between the controls and $5.0 \mathrm{ppm} \mathrm{Cd}$, while at $16 \% 0 \mathrm{~S}$ and $25 \% \mathrm{~S}$ the differences were 0.66 and $0.59 \mathrm{~mm}$, respectively (Table 1 ).

The smaller size of the larvae obtained from the $32 \% \mathrm{~S}$ experiments can be attributed to the fact that the eggs used in these trials were derived from a different female than in experiments of all other salinities.

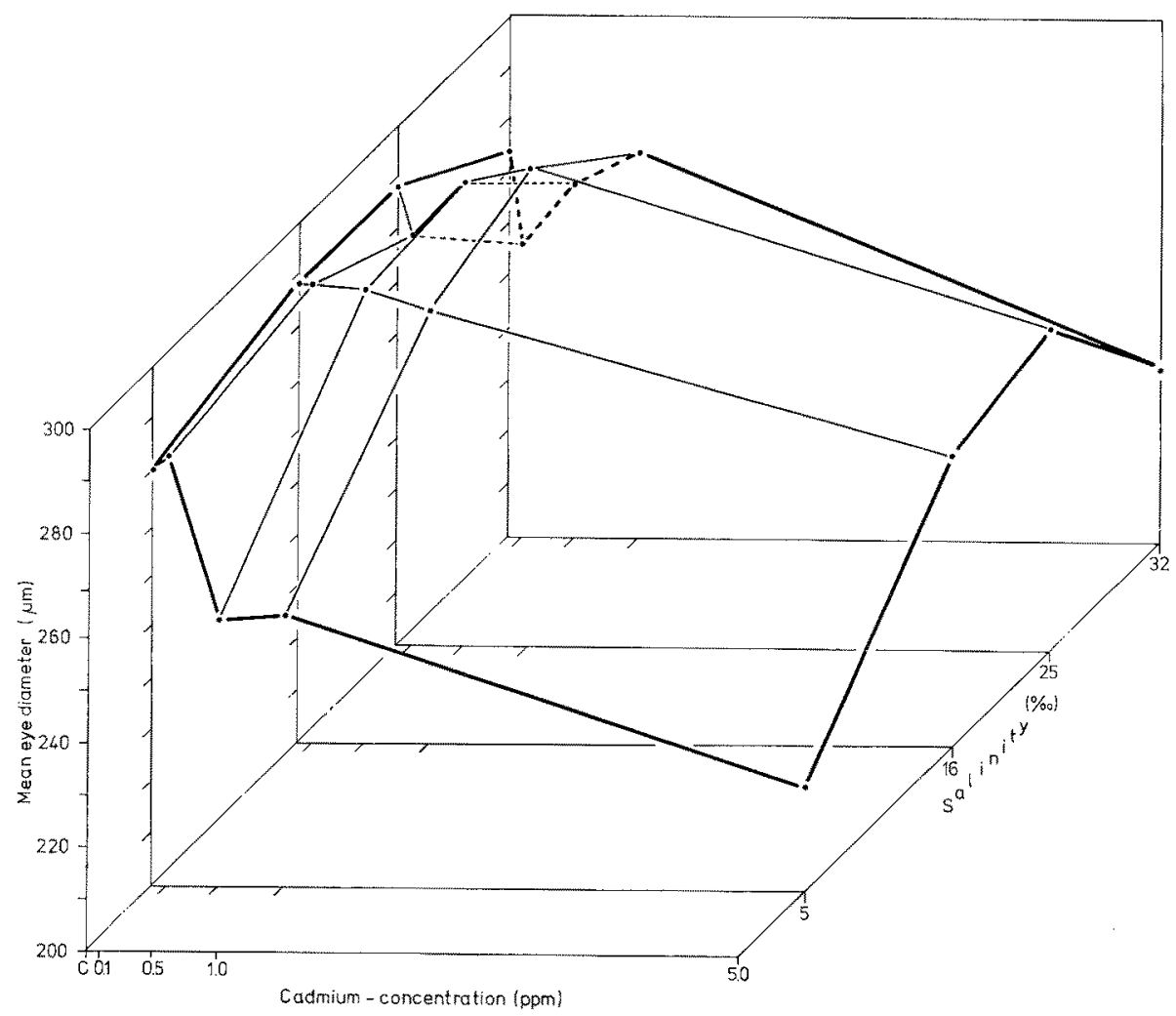

Fig. 6: Clupea barengus. Mean eye diameter of newly hatched larvae incubated at different salinity-cadmium concentrations at $10^{\circ} \mathrm{C}$. Larvae derived from incubation trials in $32 \% \mathrm{~S}$ originated from a second female. Basic statistics are given in Table 1

Eye, oticcapsule and yolksacmeasurements

At all salinities eye diameter decreased with increasing cadmium concentration. The most pronounced reductions in eye diameter were registered at $5 \% \mathrm{~S}$ (Table 1 , Fig. 6). Otic capsule diameter of newly hatched larvae remained essentially the same in $5 \%, 16 \%$, and $25 \% \mathrm{~S}$ at cadmium levels of $0.1,0.5$ and $1.0 \mathrm{ppm}$ and the 
controls. At $5.0 \mathrm{ppm} \mathrm{Cd}$ otic capsule diameter was considerably reduced (Fig. 7), capsules being smaller at $5 \%$ and $32 \% \mathrm{~S}$ than at $16 \%$ and $25 \% \mathrm{~S}$.

Yolk sac length and height of newly hatched larvae were measured. Owing to the drop shape of the yolk sac under cadmium influence, the formula for a cone was used to approximate yolk sac volume (V):

$$
V=\frac{1}{3} \pi \mathrm{r}^{2} \cdot \mathrm{h}
$$

Yolk sac volumes increased with decreasing salinity (Fig. 8), as found by RosenTHAL \& MANN (1973). In addition, at all four salinities yolk sac volume increased at higher cadmium concentrations. This was particularly evident in $5 \% \mathrm{~S}$.

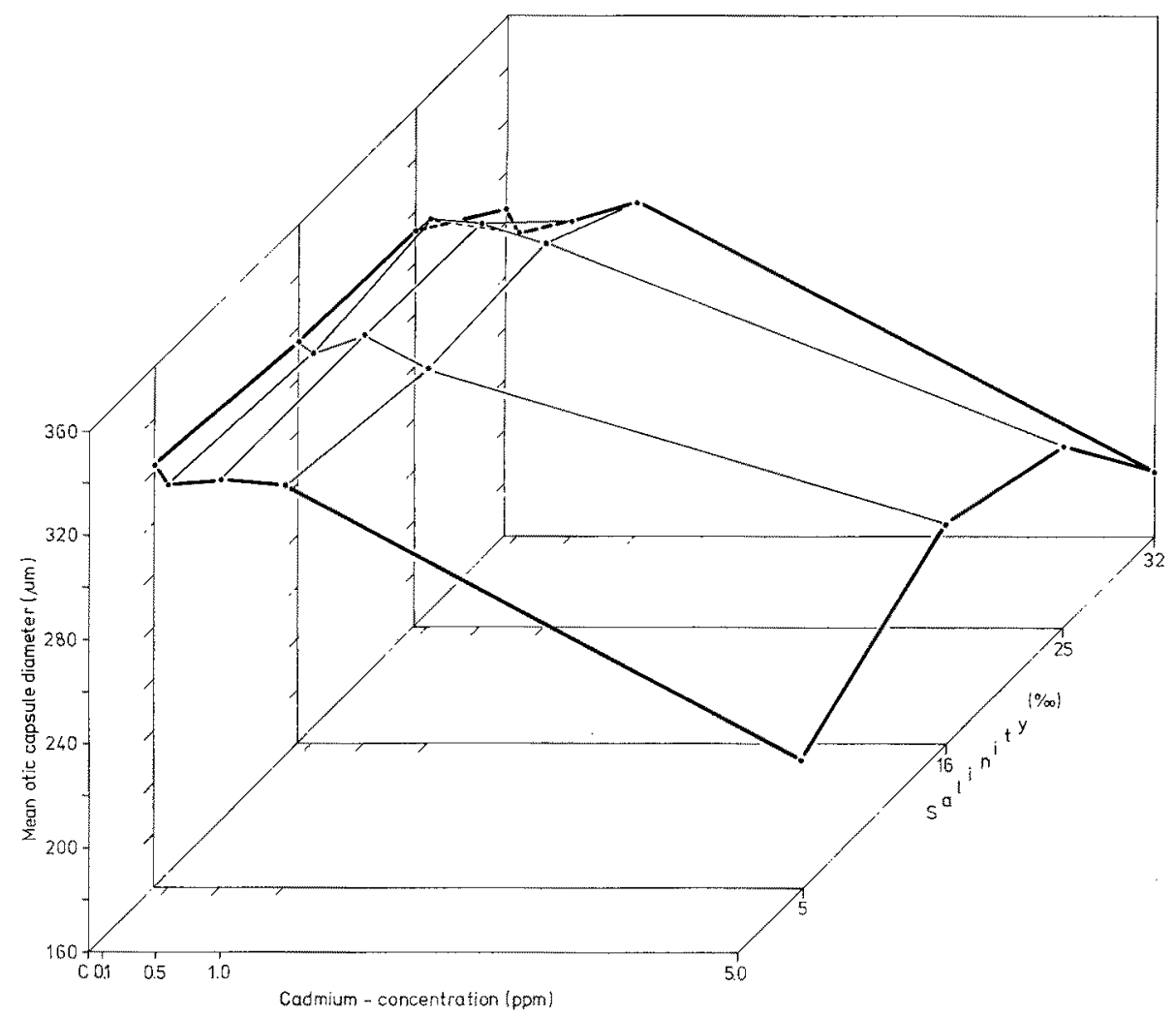

Fig. 7: Clupea barengus. Mean diameter of the otic capsule of newly hatched larvae incubated at different salinity-cadmium concentrations at $10^{\circ} \mathrm{C}$. Larvae derived from incubation trials in $32 \% 0 \mathrm{~S}$ originated from a second female. Basic statistics are given in Table 1

Cadmium uptakeduring embryonic development

Amount of cadmium accumulated by herring eggs under exposure to cadmium ions is depicted in Figure 9. Initial cadmium uptake during the first hours after 
fertilization was fairly rapid at all salinities. Highest cadmium concentrations were attained during this period. Further exposure to cadmium during development led either to declining cadmium levels in the eggs, or to stability in cadmium values as shown for $0.1 \mathrm{ppm}$ (Fig. 9). Eggs incubated in $5 \% \mathrm{~S}$ showed highest initial contamination (Fig. 9a) when compared with the respective trials at $16 \%, 25 \%$ and $32 \%$ S. Maximum levels attained depended on the initial cadmium concentrations

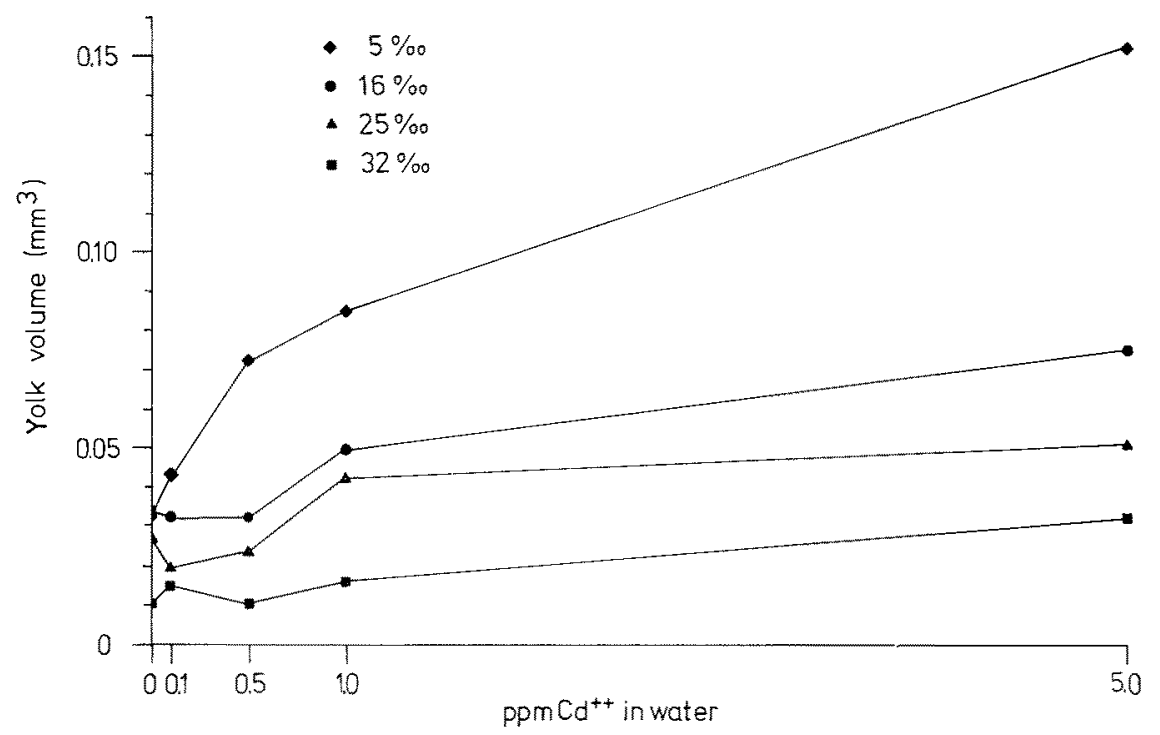

Fig. 8: Clupea barengts. Mean yolk sac volume of newly hatched larvae incubated at different salinity-cadmium concentrations at $10^{\circ} \mathrm{C}$. Larvae derived from incubation trials in $32 \% 0 \mathrm{~S}$ originated from a second female

employed in the respective tests. At $16 \%$ (Fig. 9b) cadmium concentrations in eggs, in general, were lower than those found at $5 \%$, but considerably higher than those determined for eggs incubated in $25 \%$ or $32 \% \mathrm{~S}$ (Fig. $9 \mathrm{c}, \mathrm{d}$ ). Lowest contamination values were recorded for eggs incubated at $32 \% \mathrm{~S}$.

Newly hatched larvae at all salinity-cadmium combinations contained only minute amounts of the metal, suggesting that cadmium accumulated primarily in the chorion.

\section{DISCUSSION}

The experiments indicate that toxic effects of cadmium on developing herring eggs vary considerably with the salinity of the incubating medium. In diluted sea water deleterious effects of cadmium-contaminated water on herring embryos were more pronounced than in slightly brackish or natural sea water. Prehatching mortality (Fig. 2) and malformation rates (Fig. 5) were highest in the $5 \% \mathrm{~S}$ trials. The strong detrimental effects of cadmium on herring eggs incubated in highly diluted sea water 

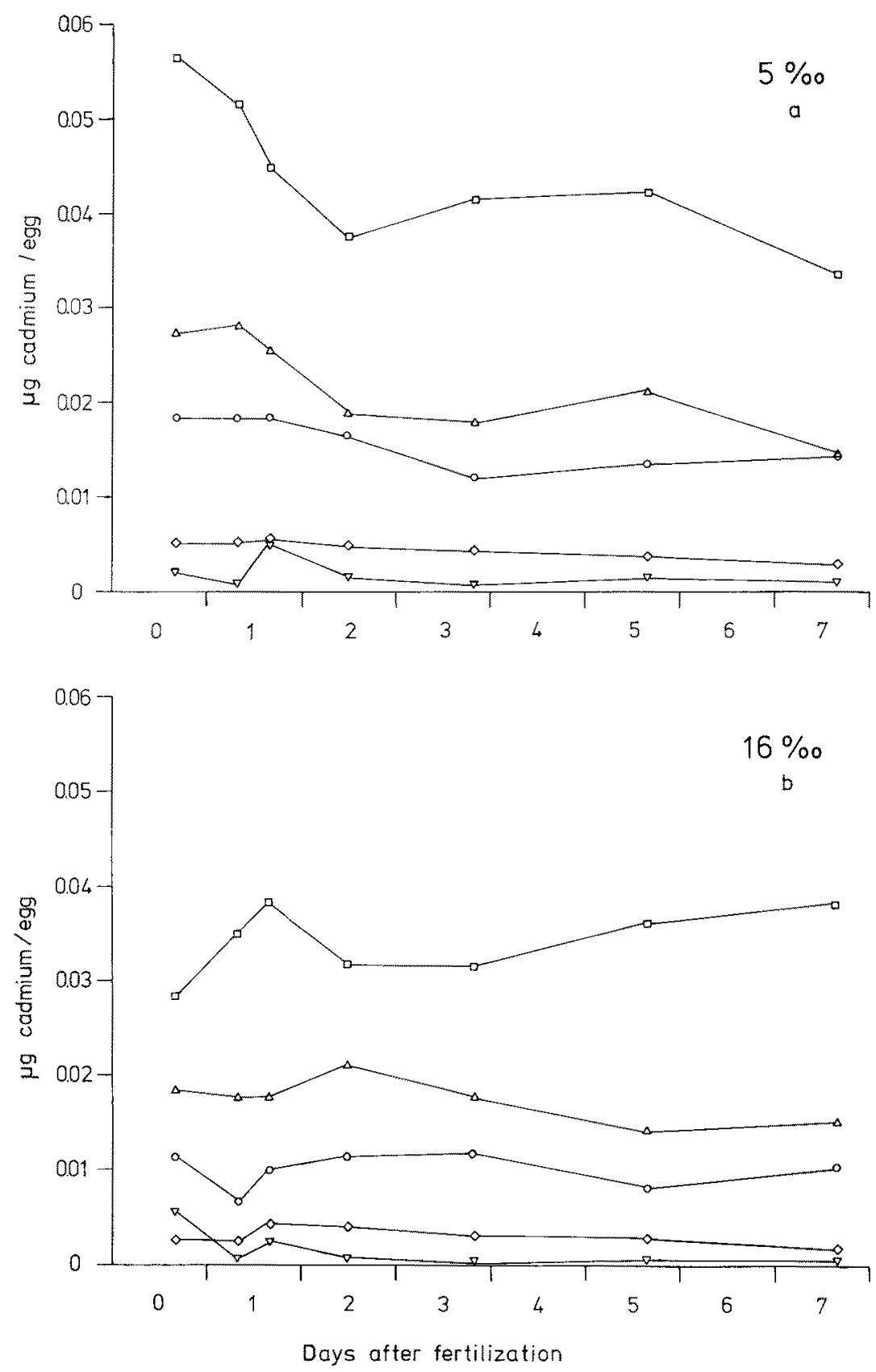

Fig. 9: a, b Clupea barengus. Mean cadmium content of eggs ( $\mu \mathrm{g} /$ individual) during incubation in different salinity-cadmium concentrations. Each value is based upon 3 to 8 determinations 

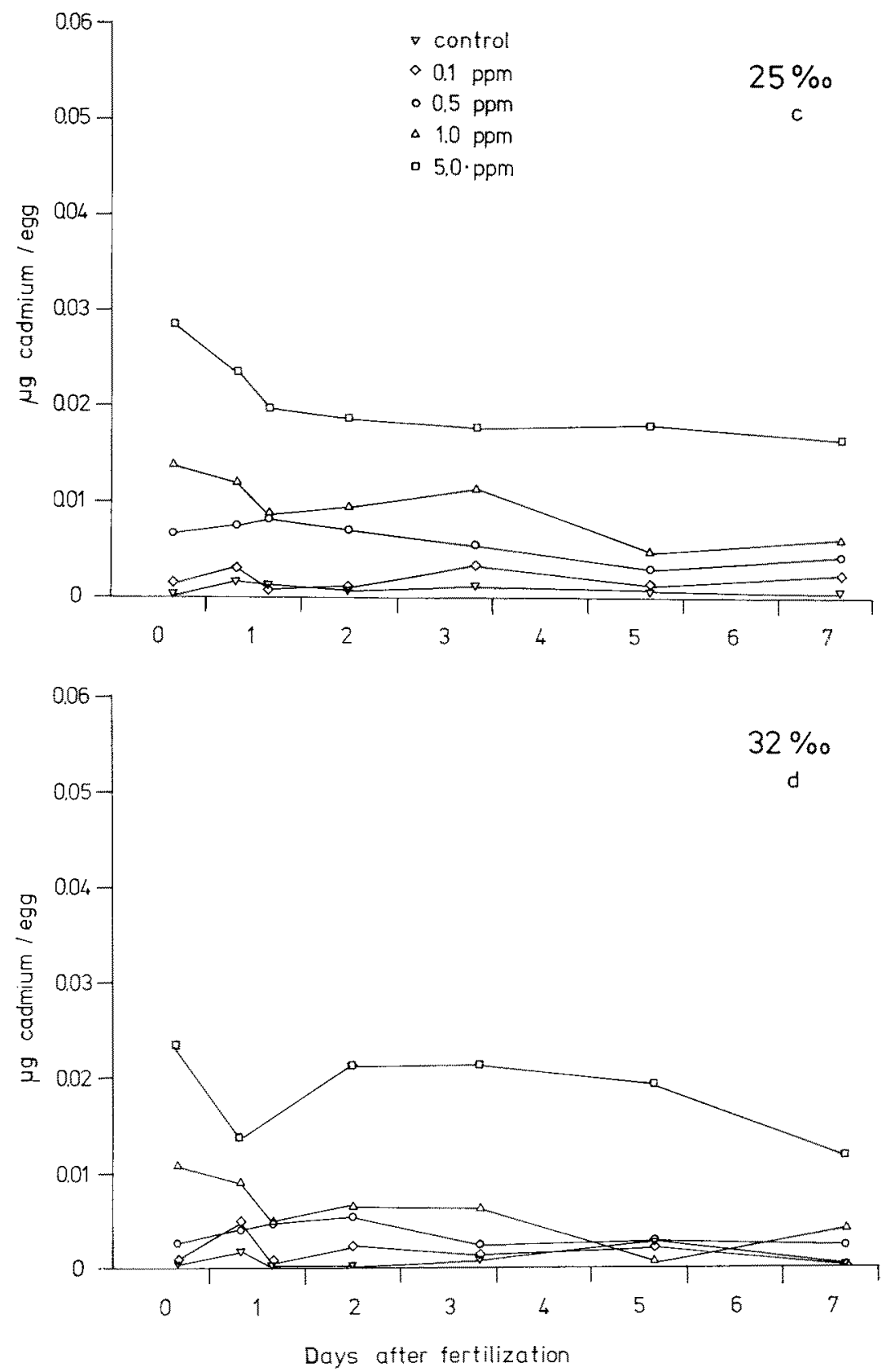

Fig. 9: c, d Clupea harengus. Mean cadmium content of eggs ( $\mu \mathrm{g} /$ individual) during incubation in different salinity-cadmium concentrations. Each value is based upon 3 to 8 determinations 
are supported by the results of the activity measurements; the least active embryos occurred at $5 \% \mathrm{~S}$ and 1.0 and $5.0 \mathrm{ppm} \mathrm{Cd}$.

The occasional high rate of survival of eggs in the incubating trial with low cadmium concentrations cannot be satisfactorily explained. EATON (1973) reported similar findings with eggs of the fathead minnow (Pimepbales promelas). It might be suggested that low cadmium levels slightly inhibit the growth of bacteria, which impede gaseous exchange at the egg membrane.

The softening of the egg membrane under the influence of cadmium indicates changes in the properties of the chorion. EAToN (1973) observed that spawned eggs from parental fish of the fathead minnow which had been chronically exposed to cadmium were more loosely attached to the substrate than those from control fish. Changes in the physico-chemical properties of the chorion may have detrimental secondary effects. Further investigations are planned in order to evaluate the physiological and ecological importance of these effects.

From Figure 8 it becomes apparent that yolk sacs of newly hatched larvae were generally larger in high cadmium concentrations than those of larvae incubated in less contaminated water. Whether this effect was caused by the shortened incubation period, as reported by RosenTHAL \& MANN (1973), or was due to the repressed activity of cadmium exposed embryos (Fig. 1) and resulting lower energy requirements cannot as yet be determined. In order to properly evaluate activities of embryos it is necessary to obtain data not only on the frequency but also on the duration of active phases. However, activity measurements seem to be useful to detect sublethal effects of pollutants. In relatively low cadmium concentrations the effects of the metal could be observed even when no morphological malformations occurred.

Not only was the deleterious effect of cadmium on herring eggs mitigated in water of higher salinities, but also the actual cadmium content of analyzed eggs dropped considerably with increasing salinity (Fig. 9). Similar findings were reported by O'Hara (1973 a). Working with the fiddler crab Uca pugilator, he found that individuals exposed to cadmium would accumulate more of the metal in low $(10 \% \mathrm{~S})$ than in high $(30 \% \mathrm{~S})$ salinities. The author attributed this phenomenon to active uptake of salts by crabs kept in brackish water. However, as reported by VeRNBERG \& O'HARA (1972) for the same species, a similar pattern for uptake of mercury apparently does not exist.

We can assume that in unpolluted water most of the cadmium added to the test solution as $\mathrm{CdCl}_{2}$ was available as uncomplexed $\mathrm{Cd}^{++}$in the water (ZiRINo \& Y YMAMoto 1972, GARDINER 1974). Thus the fact that $\mathrm{Cd}$ content of herring eggs exposed to identical contamination levels decreased with increasing salinity might suggest a mechanism of interaction between available metal ions. As reported by RosENTHAL \& SPERLING (1974), the simultaneous presence of $\mathrm{Zn}$ and $\mathrm{Cd}$ ( $\mathrm{Zn}$ being less toxic than $\mathrm{Cd}$, Danielli \& Davies 1951) increased the viable hatch of herring eggs from zero $\left(\mathrm{Cd}^{++}\right.$contaminated sea water without addition of $\mathrm{Zn})$ to $11.4 \%(\mathrm{Cd}-\mathrm{Zn}$ solution, $\mathrm{Cd}$ concentration: $5.0 \mathrm{ppm}$ ).

According to their theory and as suggested by Danielli (1944) accumulation of metal takes place only on the surface where cadmium is fixed by formation of chemical compounds with mucopolysaccharides of the chorion which acts as an unspecific ion- 
exchange medium. Thus the presence of another bivalent ion seems to trigger competition between the two lowering the amount of either fixed to or introduced into the egg. Therefore the availability of more $\mathrm{Ca}^{+t}$ or other metal ions in higher salinities might be responsible for lower $\mathrm{Cd}$ content of the eggs, mitigating toxic effects of cadmium. The apparent interaction between $\mathrm{Ca}^{++}$and $\mathrm{Cd}^{++}$ions has been pointed out by KoBayashi (1971). The extremely high cadmium susceptibility of freshwater teleosts such as Lepomis macrochirus and Micropterus salmoides (CEARLEY \& ColEman 1974), Pimephalus promelas and Lepomis macrochirus (Prckering \& Henderson 1966), and Salmo gairdnerii (BaLl 1967) compared to that of saltwater fishes such as Fundulus beteroclitus (EIsLER 1971) also suggests competitive interaction between calcium and cadmium.

The question arises as to why cadmium was not accumulated in measurable amounts inside the eggs during the incubation period. Cadmium content of the eggs during embryogenesis declined slightly under most salinity regimes (Fig. 9). The same findings have been reported by RosentHal \& SPERLing (1974) incubating eggs of Baltic herring. In contrast to this, marine fish larvae do accumulate cadmium (vON WESTERNHagen, Dethlefsen \& Rosenthal unpublished) from the surrounding water, as do crustaceans (O'Hara 1973a), molluscs (Yager \& Harry 1966, Nickless et al. 1972, Peden et al. 1973), and teleosts (EIsler et al. 1972, Cearlex \& Coleman 1974). A possible explanation lies in the assumption that the chorion, which obviously accumulates most of the cadmium in herring eggs (Rosenthal \& SperLING 1974), acts as an ion-exchange medium having the capacity of complexing or binding only a certain amount of bivalent metal ions until saturation, which could occur shortly after exposure. Thus high salinities with more competitive ions would cause lower cadmium levels in the egg membrane due to high concentrations of bivalent metals in the test medium.

Higher cadmium concentrations in the chorion would increase the chance of metal eventually seeping through the membrane into the egg as suggested by DANIELLI \& Davies (1951) for the reaction of heavy metals on cell surfaces. This would directly affect the embryo.

\section{SUMMARY}

1. Eggs of autumn spawning Baltic herring (Clupea barengus L.) were incubated in cadmium-contaminated water $(0,0.1,0.5,1.0,5.0 \mathrm{ppm})$ at four salinities $(5 \%$, $16 \%, 25 \%, 32 \%$ ) in order to evaluate possible changes in toxicity of $\mathrm{Cd}$.

2. Effects of $\mathrm{Cd}$ on embryonic survival were found to be dependent on salinity of the incubating water. Deleterious effects of $\mathrm{Cd}$ on developing herring embryos were more pronounced in brackish water than in sea water.

3. Embryonic activity, as a measure of viability of developing embryos, decreased in $\mathrm{Cd}$ concentrations with decreasing salinity.

4. In none of the trials was egg diameter altered by the $\mathrm{Cd}$ content of the incubation water. 
5. In all salinities, incubation time appeared to be shortened with increasing $\mathrm{Cd}$ content of the test medium.

6. At $5 \%, 16 \%, 25 \%$ and $0,0.1,0.5$ and $1.0 \mathrm{ppm}$, hatching rate was not significantly altered by $\mathrm{Cd}$. High hatching rates between 85 to $99 \%$ occurred in all salinity-Cd combinations. At high Cd levels (5.0 ppm), there was greater survival of embryos at high salinities $(32 \%$ and $25 \%$ ) than at low salinities $(16 \%$ and $5 \%$ ).

7. Percentage viable hatd was unaffected at $32 \%, 25 \%$ and $16 \% \mathrm{~S}$ and $0,0.1$ and $0.5 \mathrm{ppm} \mathrm{Cd}$. In low salinities $(5 \%)$, only $1 \%$ viable hatch occurred at $0.5 \mathrm{ppm}$; in $16 \%$ viable hatch occurred at $1.0 \mathrm{ppm} \mathrm{Cd}$. No viable larvae were obtained in any tests at $5.0 \mathrm{ppm} \mathrm{Cd}$.

8. In all salinities examined, mean total length of newly hatched larvae decreased with increasing $\mathrm{Cd}$ concentration of the rearing medium. Relative decrease in mean total length was minimum at $32 \% \mathrm{~S}$.

9. In all four test concentrations yolk sac volumes of newly hatched larvae increased with rising $\mathrm{Cd}$ concentrations, probably associated with declining embryo activity.

10. The Cd content of eggs was found to be generally higher in lower salinities than in more saline water at comparable $\mathrm{Cd}$ concentrations.

\section{LITERATURE CITED}

Abdullah, M. J., Royle, L. G. \& Morris, A. W., 1972. Heavy metal concentration in coastal waters. Nature, Lond. 235, 158-160.

Andersen, A. T., Dommasnes, A. \& Hesthagen, I. H., 1973. Some heavy metals in sprat (Sprattus sprattus) and herring (Clupea harengus) from the inner Oslofjord. Aquaculture 2, 17-22.

BALL, I. R., 1967. The toxicity of cadmium to rainbow trout (Salmo gairdnerii Richardson). Wat. Res. 1, 805-806.

Biesinger, K. E. \& Christensen, G. M., 1972. Effects of various metals on survival, growth, reproduction, and metabolism of Daphnia magna. J. Fish. Res. Bd Can. 29, 1691-1700.

Brown, B. \& Ahsanullah, M., 1971. Effect of heavy metals on mortality and growth. Mar. Pollut. Bull. 2, 182-187.

Butterworth, J., Lester, P. \& Nickless, G., 1972. Distribution of heavy metals in the Severn estuary. Mar. Pollut. Bull. 3, 72-74.

Cearley, J. E. \& Coleman, R. L., 1974. Cadmium toxicity and bioconcentration in largemouth bass and bluegill. Bull. environ. Contam. Toxicol. 11, 146-151.

Chester, R. \& Stoner, J. H., 1974. The distribution of zinc, nickel, manganese, cadmium, copper, and iron in some surface waters from the world ocean. Mar. Chem, 2, 17-32.

Connor, P. M., 1972. Acute toxicity of heavy metals to some marine larvae. Mar. Pollut. Bull. 3, 190-192.

Danielli, J. F., 1944. The biological action of ions and the concentration of ions at surfaces. J. exp. Biol. 20, 167-176.

- \& Davies, J. T., 1951. Reactions at interfaces in relation to biological problems. Adv. Enzymol. 11, 35-89.

EAton, J. G., 1973. Chronic toxicity of a copper, cadmium and zinc mixture to the fathead minnow (Pimephales promelas RafrNesQue). Wat. Res. 7, 1723-1736.

Eisler, R., 1971. Cadmium poisoning in Fundulus beteroclitus (Pisces: Cyprinodontidae) and other marine organisms. J. Fish. Res. Bd Can. 28, 1225-1234. 
- Zarooglan, G. E. \& Hennekey, R. J, 1972. Cadmium uptake by marine organisms. J. Fish. Res. Bd Can. 29, 1367-1369.

Gardiner, J., 1974. The chemistry of cadmium in natural water. 1 . A study of cadmium complex formation using the cadmium specific-ion electrode. Wat. Res. 8, 23-30.

Goldberg, E. D., 1965: Minor elements in sea water. In: Chemical Oceanography. Ed. by J. P. Rrley \& G. Skirrow. Academic Press, New York, 1, 163-196.

Holliday, F. G. T., Blaxter, J. H. S. \& Lasker, R., 1964. Oxygen uptake of developing eggs and larvae of the herring (Clupea barengus). J. mar. biol. Ass. U.K. 44, 711-723.

Jones, P. G. W., Henry, J. L. \&. Folkard, A. R., 1973. The distribution of selected trace metals in the water of the North Sea 1971-1973. Coun. Meet. int. Coun. Explor. Sea (= C.M.-I.C.E.S.) 5 .

Kobayashi, J., 1971. Relation between the "itai-itai" disease and the pollution of river water by cadmium from a mine. Adv. Wat. Pollut. Res. 1, 1-32.

Kremling, K., 1973. Voltametrische Messungen über die Verteilung von Zink, Cadmium, Blei und Kupfer in der Ostsee. Kieler Meeresforsch. 29, 77-84.

Leatherland, T. M. \& Burton, J. D., 1974. The occurrence of some trace metals in coastal organisms with particular reference to the Solent region. J. mar. biol. Ass. U.K. 54, $457-468$.

Mullin, J. B. \& Rrley, J. P., 1956. The occurrence of cadmium in seawater and in marine organisms and sediment. J. mar. Res. 15, 103-122.

Nickless, G., Stenner, R. \& Terrille, N., 1972. Distribution of cadmium, lead and zinc in the Bristol Channel. Mar. Pollut. Bull. 3, 188-190.

O'Hara, J., 1973a. Cadmium uptake by fiddler crabs exposed to temperature and salinity stress. J. Fish. Res. Bd Can. 30, 846-848.

- 1973b. The influence of temperature and salinity on the toxicity of cadmium to the fiddler

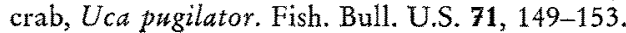

Orson, K. R. \& HARREL, R. C., 1973. Effect of salinity on acute toxicity of mercury, copper and chromium for Rangia cuneata (Pelecypoda, Mactridae). Contr. mar. Sci. 17, 9-13.

Peden, J. D., Crothers, J. H., Waterfall, C. E. \& Beasley, J, 1973. Heavy metals in Somerset marine organisms. Mar. Pollut. Bull. 4, 7-9.

Pickering, Q. H. \& Henderson, C., 1966. The acute toxicity of some heavy metals to different species of warm water fishes. Int. J. Air Wat. Pollut. 10, 453-463.

- \& GAST, M., 1972. Acute and chronic toxicity of cadmium to the fathead minnow (Pime phales promelas). J. Fish Res. Bd Can. 29, 1099-1106.

Preston, A., 1973. Heavy metals in British waters. Nature, Lond. 242, 95-97.

- Jeffries, D. F., Dutton, J. W. R., Harwey, B. B. \& Steele, E. K., 1972. British Isles coastal waters: The concentrations of selected heavy metals in sea water, suspended matter and biological indicators - a pilot survey, Environ. Pollut. 3, 69-82.

Rosenthal, H., 1966. Leaving the egg sheil. A film on the hatching of herring larvae. Coun. Meet. int. Coun. Explor. Sea (C.M.-I.C.E.S.) 3, 1-3.

- \& MANN, H., 1973. Wirkung eines proteolytischen Enzyms (Maxatase-P) auf Embryonen des Herings (Clupea harengus) bei unterschiedlichen Temperaturen und Salzgehalten. Arch. FischWiss. 24, 217-236.

- \& SRERling, K. R., 1974. Effects of cadmium on development and survival of herring eggs. In: The early life history of fish. Ed. by J. H. S. BLAXTER. Springer, Berlin, 383-396.

SchweIger, G., 1957. The toxic action of heavy metal salts on fish and organisms on which fish feed. Arch. FischWiss. 8, 54-78.

Thurberg, F. P., DAwson, M. A. \& Lollier, R. S., 1973. Effects of copper and cadmium on osmoregulation and oxygen consumption in two species of estuarine crabs. Mar. Biol. 23, $171-175$.

VERNBERG, W. B. \& O'HARA, J., 1972. Temperature-salinity stress and mercury uptake in the fiddler crab, Uca pugilator. J. Fish. Res. Bd Can. 29, 1491-1494.

Windom, H. L. \& SMITH, R. G., 1972. Distribution of cadmium, cobalt, nickel and zinc in southeastern United States continental shelf waters. Deep Sea Res. 19, 727-730. 
YAGER, C. M. \& HARRY, H. W., 1966. Uptake of heavy metal ions by Taphius glabratus, a snail host of Schistosoma mansoni. Expl. Parasit. 19, 174-182.

Zirino, A. \& YамAмото, S., 1972. A pH-dependent model for the chemical speciation of copper, zinc, cadmium, and lead in sea water. Limnol. Oceanogr. 17, 661-671.

First author's address: Dr. H. von Westernhagen

2 Hamburg 50

Biologische Anstalt Helgoland

Zentrale Hamburg

Palmaille 9

Federal Republic of Germany 